\title{
Inclusive ecosystem model for the management of knowledge, training and innovation: progress, difficulties and challenges
}

\author{
Emilio Álvarez-Arregui*, Alejandro Rodríguez-Martín*, Susana Agudo Prado*, Xavier Arreguit** \\ ${ }^{*}$ Universidad de Oviedo, ${ }^{* *}$ Director General de Innobridge SA, (Suiza)
}

\begin{abstract}
Relations between Society and Education are being reconsidered at each significant point in time based on the current situation and facts. Taking into account the possibilities and limitations of the economic, social and cultural climates, it is therefore necessary to make continuous adjustments depending on the actual stage of development of the concurrent ecosystems, considering also their integrating elements, in order to synchronize the development of shared projects in the short, medium and long term in all environments: political, business, academic and social,

In this framework, we have been progressing in recent years, in both theory and practice, in the construction, the development and the implementation of an inclusive ecosystem model that integrates training, research and innovation of professionals and users to provide comprehensive answers to the needs and demands of involved organizations, institutions, as well as of the citizens in general. The ecosystem model serves as a platform to manage knowledge and a network of institutions.

In this article we present some of the projects that we are supporting from the Institute of Research and Educational Innovation (INIE) of the University of Oviedo, as well as the difficulties we are encountering, the progress and future challenges.
\end{abstract}

Keywords: ecosystem of training, social inclusion, didactic methodology, collaborative learning, knowledge management, teaching practice, combined teaching.

\section{Modelo ecosistémico inclusivo para la gestión del conocimiento, la formación y la innovación: avances, dificultades y retos}

\section{RESUMEN}

Las relaciones entre Sociedad y Educación se van reinterpretando en cada momento histórico concreto en base a circunstancias situacionales. Ante esta realidad se hace necesario realizar ajustes continuados en función del estadio de desarrollo en que se encuentren los ecosistemas concurrentes, así como elementos que los integran para sincronizar el desarrollo de proyectos compartidos a corto, medio y largo plazo en los ámbitos políticos, empresariales, académicos y sociales atendiendo a las posibilidades y límites coyunturales, situacionales y culturales.

En este escenario venimos avanzando en los últimos años, desde la teoría y la práctica, en la construcción, desarrollo e implementación de un modelo ecosistémico inclusivo que integra la formación, la investigación y la innovación desde el que gestionamos el conocimiento y las redes de instituciones, de profesionales y usuarios para dar respuestas integrales a las necesidades y demandas de las organizaciones con las que interactuamos y de la ciudadanía en general.

En este artículo presentamos algunos de los proyectos que estamos respaldando desde el Instituto de Investigación e Innovación Educativa (INIE) de la Universidad de Oviedo, así como las dificultades que nos estamos encontrando, los avances y los retos de futuro.

Palabras Clave: ecosistema de formación, inclusión social, metodología didáctica, aprendizaje colaborativo, gestión del conocimiento, práctica docente, enseñanza combinada.

\section{Introduction}

Society, education and the university need to reconsider their relationships at each historical moment based on the priorities or codes of behavior that are deemed appropriate by the entities, governments, businesses or advocacy-groups that can take decisions according to the available resources and in order to answer to the needs or demands of the population, in general, and of the organizations, professional, workers, researchers, students, specifically. If we accept this argument, then we accept the premise that society is in constant transformation (Toffler, 1980) due to its technological, global, informational 
(Castells, 1999) and fluid (Area, 2012) characteristics, and that communication influences the basic axes that guide the way of life and the behaviors of people, professionals and researches in their social, work, political, economic, cultural and personal environments (Álvarez-Arregui et all. 2017).

The speed of change taking place in our Society is unprecedented. Its effects are unequally spread between the economy, the politics, the organizations and the communities. Several reasons can be pointed out, although in our opinion, some facts are difficult to question. Just consider how in the last decades four constructs (Macro Trends) have been interdependently developping and affecting the basic axes of our lives, namely: Neoliberalism (Bell, 1991; Gimeno Sacristán, 2001). Technology (Dosi, Freeman, Richard, Silverberg and Soete, 1990), Globalization (Castells, 1999) and Knowledge (Drucker, 1969; Böhme y Stehr, 1986; Morin, 2002).

The peculiarity of these Macro Trends is their capacity at interacting with each other and integrating feedback, thus generating "nonlinear dynamics" resulting in exponential accelerations in the change of structural and functional systems, affecting people's lives.

The theories of communicative action (Habermas, 1987) or reflexivity (Beck, Giddens and Lash, 1997) point us to the existence of multiple possibilities to access knowledge and knowhow, to relate to each other, to enjoy ourselves and to work, but also to warn us about the need to perceive the values and myths that are granted or associated with technological development. At this point it is necessary to discern that information is not knowledge. This nuance is fundamental because it associates knowledge with the ability to have a critical sense enabling to filter data discriminately. This should make us reflect on the responsiveness of the Educational institutions which are facing a paradigm of complexity that advocates for the construction of a learning environment that is more ecosystemic, entrepreneurial, creative and interdisciplinary. It requires of people to understand training as a vital process of adaptation, acceptance and understanding of change (Álvarez Arregui, 2002, 2008, 2010, Álvarez Arregui and Rodríguez Martín, 2011, 2012, 2013, 2014, 2015, 2016, 2017).

The emergent context associated with the above-mentionned constructs leads to a reconstruction of citizen participation (social axis) because of the increasing gap between the population and the political system which has lost credibility, and also because of the increasing offshoring of relevant decisions directly affecting people and their future, and also because of the depreciation of the socialization impact of classic institutions, and also because of the emergence of socio-educational agents in spaces left open by the State - i.e. the third sector, and also because of the emergence of new solidarities, and also because of the increase of the migratory flow with different-impact consequences in both originating and fostering societies (cultural axis). Autonomy, freedom, competitiveness and dependence contribute to the construction of a subjectivity that ignores the individual when it opts for the group or the mass in a consumerist context, meaning a loss of secure references for anchoring a life project (personal axis). Labor reforms are also a consequence of the pressure applied by the aforementioned macro trends (labor axis) in such a way that we are witnessing a redefinition of the relationship between capital and labor, of the role of social agents, of the contracting systems, and the emergence of new professional profiles (Álvarez Arregui, Rodríguez Martín and Ribeiro Gonçalves, 2011).

The responsiveness of universities and their orientation is thus constrained or favored based on how the normative framework is articulated. Thus, governments have to assume their share of responsibility for the commitments made publicly and the decisions taken. The market logic derived from the above-mentioned constructs also highlights the guidelines under which universities are governed and with them the systems of relationships established among these institutions, but also among the professors, between professors and students, among students, between professors and staff in the administration and services, among themselves and, in general, between University and Society (figure 1).

It is, therefore logical, that indiscriminate marketization of higher education ends up generating paradoxes, contradictions and inequities difficult to predict. In this context it seems important to recall the social responsibility of universities, at least of public universities, so that this mission is a key reference in the design of their strategies. De facto, the so-called Bologna Process defended the establishment of a higher education system promoting social cohesion and reducing inequalities.

In this framework, it seems logical that universities are looking into improving their situation in the international rankings, and consequently that within the University of Oviedo a Campus of International Excellence has emerged.

Figure 1. Macro-trends and reference axes in today's society (Álvarez-Arregui, E, Rodríguez-Martín and Arreguit, X.).

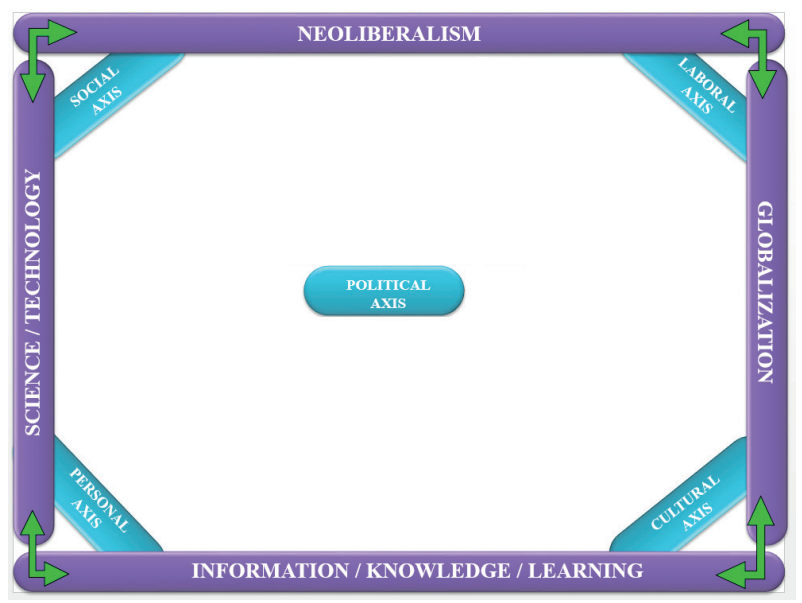

The difficulty we face is that demagogic discourses about the merits of the strategies that are deployed in our universities by the rectory teams and decannals must be translated into viable, shared, responsible and inclusive training, innovation and research projects. We cannot continue talking about what others should do, expecting more from teachers, or more from service staff, or more from students... or continuously shifting the responsibilities of the decisions related to managing politics at a general level, or at the level of universities or institutions. Waiting idle to see what happens would have devastating results if decisions are not made, or committed, shared, effective, local and grounded, only leading to growing problems, more so if the discourse on change and improvement of universities follows a thinking that is unique, uniform, imposed and decontextualized.

The current situation, although difficult, could be improved if we are able to take advantage of synergies generated when implementing and continuously adapting the curricula, deploying actions that overcome the limitations highlighted. As we have stressed on many occasions, in dynamic spaces with high uncertainty, it is impossible to find organizing structures and generalizable systems. Therefore, the organizations' missions 
and visions must take into account the situational outcome from the analysis of their respective ecosystems.

In institutions of higher education, we should and must learn to change and accept change. If we review, update and implement curricular designs and promote lines of research with a transdisciplinary, ecoforming and intercultural approach, the improvement will be viable and the adaptation possible.

Nevertheless, from a training perspective, it cannot be denied that there have been many advances contributed by research studies, highlighting, among others, the importance that is attributed to the learner (León \& Latas); the institutional environment(Ramdsden, Martin \& Bouden, 1989); the classroom context (Entwistle \& Tait, 1990); the pedagogic competence (Sánchez Gómez \& García-Valcarcel, 2002); the use of technology and social networks (García-Galera, 2013); collaboration (Kolloffel, Eysink, \& Jong, 2011); the curriculum (GimenoSacristán, 2001; 2008); the promoted active methodologies (Cano, 2009); the revision of study plans (Zabalza, 200); the revision of teaching and research learning processes (Carrascosa, 2005); the need to constantly review the processes from a formative evaluation (Monereo, 2009) or the repercussions of the transfer of misuse of knowledge generated from research (Buckland, 2009), for example.

In our case, we have been developing in the last years several ecosystemic training projects that go beyond the standardized proposals. Standardized proposals that are generally insufficient to generate changes in professional cultures or to provide the required competences to the recipients of information and knowledge.

Broadly speaking, based on an ecosystem, we are expanding and promoting public learning, building a model of education and training, and innovation and research, focusing on learning how to undertake and learning how to change. This organizational proposal is inspired by the learning organizations (Senge, 1990) and by innovation acceleration platforms, highlighting some basic principles of its design and operation, like rationality, flexibility, permeability, collegiality, professionalism, multidisciplinarity, self-management, creativity, inclusivity, transferability and complexity, and optimizing available teaching resources and adapting the necessary teaching modalities to a globalized learning environment.

The rationale is simple: promote a continuous improvement process. This process enables to discover new ideas, to integrate them, to transform them and to steer them to meet the objectives. In other words, we provide to the model the ability to learn and grow inside and outside the institution.

Virtual platforms are subject to special attention. For some participants it may be the only space available for relationships and communication when the integration into the ecosystem is considered from the non-presential mode; hence during planning and initial diagnosis we keep in mind those available resources, as well as knowledge acquired and materials generated by previous projects in which we have participated. Our proposal has been endorsed by the results that we have been achieving, considering theoretical, practical and empirical references, together with the design of educational institutions as "ecosystems", linked to the support provided by universities, institutes of research and educational innovation, international ecosystems of innovation.

\section{Training ecosystems in university teaching}

Training ecosystems in higher education are relatively recent, although there are currently many innovative experiments that are promoting dynamic and collaborative relationships between community members. Among the promising proposals, we find the Modular ecosystem (Dimitrov, 2001); the Knowledge ecosystem (Shrivastava, 1998); the e-learning ecosystem for management and support of learning (Ismail, 2001); the e-learning ecosystem for governance (Chang \& Lorna, 2008) or the learning ecosystem (LES) of Gült and Chang (2009). These models incorporate learning design, human resources, and training for the development of basic competencies, a communication system and different applications (Shimaa, Nasr \& Helmy, 2011).

Although we coincide with the basic tenets, we believe, as other authors, that the dangers derived from an excessive shift towards e-learning should be analyzed (Uden, Wangsa \& Damiani, 2007), as the communication potentials that in-person learning technologies bring, could be wasted. This is the reason why we prefer to align ourselves with blended-learning models.

In this sense we consider the need to promote and propose training and content showing transversal, longitudinal, inclusive and sustainable qualities. It requires the design, construction and implementation of comprehensive training models based on ecosystems that are adaptable to the needs of audiences.

\section{Our model of a learning ecosystem: learn to undertake and change}

Considering the research works cited above, we have been developing a model at the University of Oviedo that we have applied to training projects in education, social and work areas as well as in innovation and research projects (figure 2) that aim to develop professional communities of learning that are interconnected, cohesive and self-regulating within national and international institutions. The construction of this ecosystem is the result of setting questions and planning a reference structure that is flexible and dynamic that can be continuously perfected thanks to diagnosis, evaluations and research.

\section{The basic design of the model is composed of seven phases:}

\section{Phase I. Planning and diagnosis.}

Instruments that provide us with information at the start and the end of the process are prepared to determine the needs and the impact of the education intervention. The user's complete diverse questionnaires (study habits, communication and digital competency, learning styles, etc.).

\section{Phase II. Design of the training context.}

This is constructed around two spaces, the virtual and the inperson. The virtual surroundings adopt a modular, scalable and adaptable structure (figure 3):

- Information module. Here we incorporate the degree's documentation, the official program of the course, the general bibliography and the news forum.

- Communication module. In this module, all the available communication tools available are included (forum, Skype, blog, Facebook, Twitter, etc.).

- Diagnostic module. The elements allow the user body to understand their learning styles, study habits, media competency and previous knowledge. In Dropbox, Google calendar... and in general forums, we collect what is expected and the perceptions on the subjects, which will be compared at the end of the academic year. 
- Theory module. A general guideline of the contents, schemes, links, bibliographic references, presentations (PowerPoint, Prezzi...) are included here, so that all the participants (users and professionals) can access them.

- Practices module. Individual, group, in-person and virtual activities are planned.

- Self-management and learning support module. A bank of resources and good-practices are found here.

- Research and impact assessment module. Here we find the official external assessments that are conducted by the Technical Quality Unit from the University of Oviedo and internal evaluations, where we find the information provided in the forums, the blogs, the social networks, in the classroom debates and the research studies.

Phase III. Deployment of the learning model. This is done through four systems:

- Registration and information system.

- Tutoring and counselling system.

- Relations and communications system.

- Self-assessment of learning system.

In this phase, all kinds of tools are deployed so that the participants acquire the skills that have been determined for the presentation, the workshop, the seminar...

As an example we present a brief list to illustrate the way we work. Tools: Face to face; Personal objects; Shared stories; Business card; Jigsaw; Case study; Role Play; Benchmarking; Brainwriting;
Pareto Diagram; Ishikawa Diagram; SWOT Analysis; Coaching; Six Thinking Hats; Snowball; Traveling Suitcase; Mental Schemes; The Rumor; Spider Web; Visors; Johari Window; Origami; Complicated Avenue; Interview; The cake; Europass; Metaplán; $360^{\circ}$ evaluation; Curious questionnaire; Spaghetti tower; Lotus flower; Imaginary DNI; Video CV; Lost on Mars; Video Forum; Lecture; Seminar; Round Table; Symposium; Congress; Pedagogical Visits; Films; Theatre; Performance; Virtual Forums; Twitter; Facebook; Skype; Blogs; Problem Based Learning; Service Learning; Project Based Learning, Peer-to-peer (P2P)... (Álvarez-Arregui y Rodríguez-Martín, 2011, 2012, 2013, $\underline{2014,2015,2016,2017)}$

\section{Phase IV. Evaluation of improvement}

This module is structured into three sections:

- First. This shows the results of the evaluations that are conducted by the Technical Quality Unit from the University of Oviedo or external or internal evaluation institutions to be determined.

- Second. This collects the public opinions (blogs, forums, Facebook, Twitter...) given by the users on the methodologies that are being implemented.

- Third. It compares the initial diagnostic of the participant's profiles with their state at the end of the process; their degree of satisfaction with the training ecosystem, and the competencies acquired are determined.

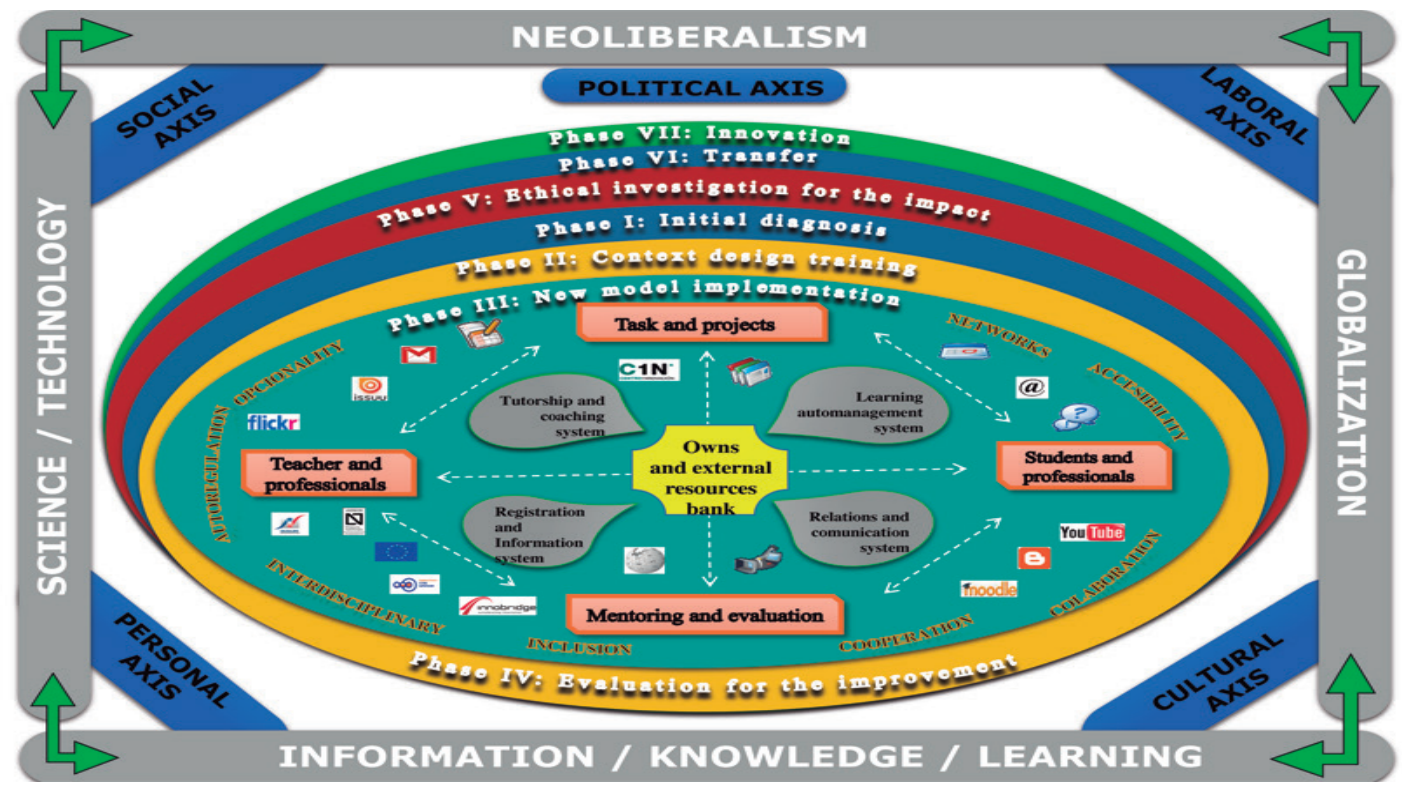

Figure 2. Training eco-environment (Álvarez-Arregui, Rodríguez-Martín y Arreguit.).

\section{Phase V and Phase VI. Research on impact and Transfer.}

Periodical research studies on the processes, results and the model design are conducted.

Taking into account this design, we put forward this research work, with the aim of determining the degree of self-perception the participants have about the content, and to analyze the degree of influence that the blended-learning ecosystems have within it when used as a training modality. More specifically, we aim (Álvarez-Arregui et all, 2017):
- To understand how the participating university students perceive the contents.

- To evaluate the indicators of contents that are more important for the participans.

- To determine the impact of the training ecosystems in the self-perceived media competency.

- To analyze the value that the participants grant to the training ecosystems. 
Figure 3. Virtual environment modules (Álvarez-Arregui and Rodríguez-Martín, 2013).

\begin{tabular}{|l|ll|l||}
\hline 1 & $\begin{array}{l}\text { Módulo de } \\
\text { información }\end{array}$ & $\begin{array}{l}\text { Módulu } \\
\text { d'información }\end{array}$ & $\begin{array}{l}\text { Information } \\
\text { Module }\end{array}$ \\
\hline \hline
\end{tabular}

\begin{tabular}{|c|c|c|c|}
\hline$\frac{1}{2}$ & $\begin{array}{l}\text { Módulo de } \\
\text { comunicación }\end{array}$ & $\begin{array}{l}\text { Módulu de } \\
\text { comunicación }\end{array}$ & $\begin{array}{l}\text { Communication } \\
\text { Module }\end{array}$ \\
\hline
\end{tabular}

\begin{tabular}{|ll|l||} 
Módulo de & Módulu de \\
diagnóstico & $\begin{array}{l}\text { Diagnostic } \\
\text { Module } \\
\text { diagnósticu }\end{array}$ &
\end{tabular}

\begin{tabular}{||l|ll||}
\hline \hline & $\begin{array}{l}\text { Módulo de } \\
\text { contenidos } \\
\text { teóricos }\end{array}$ & $\begin{array}{l}\text { Módulu de } \\
\text { conteníos teóricos }\end{array}$ \\
\hline
\end{tabular}

\begin{tabular}{||l|ll||}
\hline \hline & $\begin{array}{l}\text { Módulo de } \\
\text { prácticas }\end{array}$ & $\begin{array}{l}\text { Módulu de } \\
\text { práctiques }\end{array}$
\end{tabular}

\begin{tabular}{||l|lll||}
\hline $\begin{array}{l}\text { Módulo de } \\
\text { autogestión y apoyo } \\
\text { al aprendizaje }\end{array}$ & $\begin{array}{l}\text { Módulu } \\
\text { d'autoxestión y } \\
\text { sofitual aprendizaxe }\end{array}$ & $\begin{array}{l}\text { Self-management and } \\
\text { learning support } \\
\text { Module }\end{array}$ \\
\hline
\end{tabular}

The group of researchers of the University of Oviedo want to share this ecosystem of training on which we are working to improve it, adapt it and restructure it, attending to the objectives, difficulties and possibilities that are emerging in the development and implementation of this investigation project.

The deployment of the training ecosystems mediated by technology is significant in its use of time and resources, but it can orient processes of change in those Higher Learning institutions where ambiguity of objectives, decoupling and

\section{Phase VII. Innovation}

The final phase, of course, is innovation, that is, the realization of a change in the behaviour, in their work environment, of people participating in the training process and which is linked to the objectives. An example of the modules that we use in the virtual environment of training and learning can be seen in the attached figure. Depending on the audience, the languages, the tools, the contents and the methodologies are adapted.

The process that we use to generate ideas and develop and implement projects can be seen in Figure 4. The fundamental basis of the ecosystem is the collaboration with other institutions, profesionals and students; our objective being the development of the improvement of education in the organizations to provide the best learning experiences to citizens.

Figure 4. Fractal structure for innovation with a model of training eco-environment (Álvarez-Arregui and Arreguit).

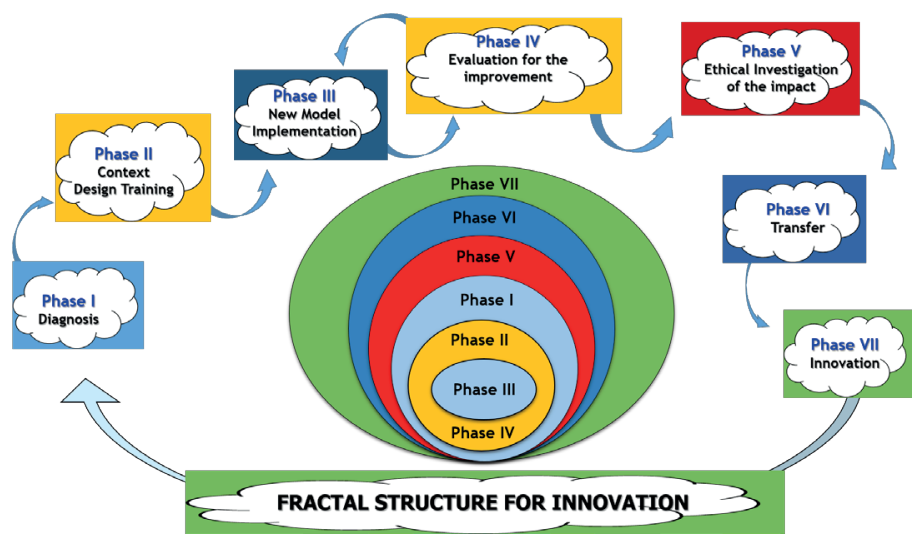

diversity of interests dominate over collaboration, innovation and continuous improvement.

Finally, we present another scheme with which we work habitually for the development of projects with the participation of partners and providers of resources incorporated directly or indirectly in the specific ecosystem that is built for the particular occasion. We consider it very illustrative because it clarifies how we work at different levels and contexts simultaneously, to give the most appropriate answers in each case.

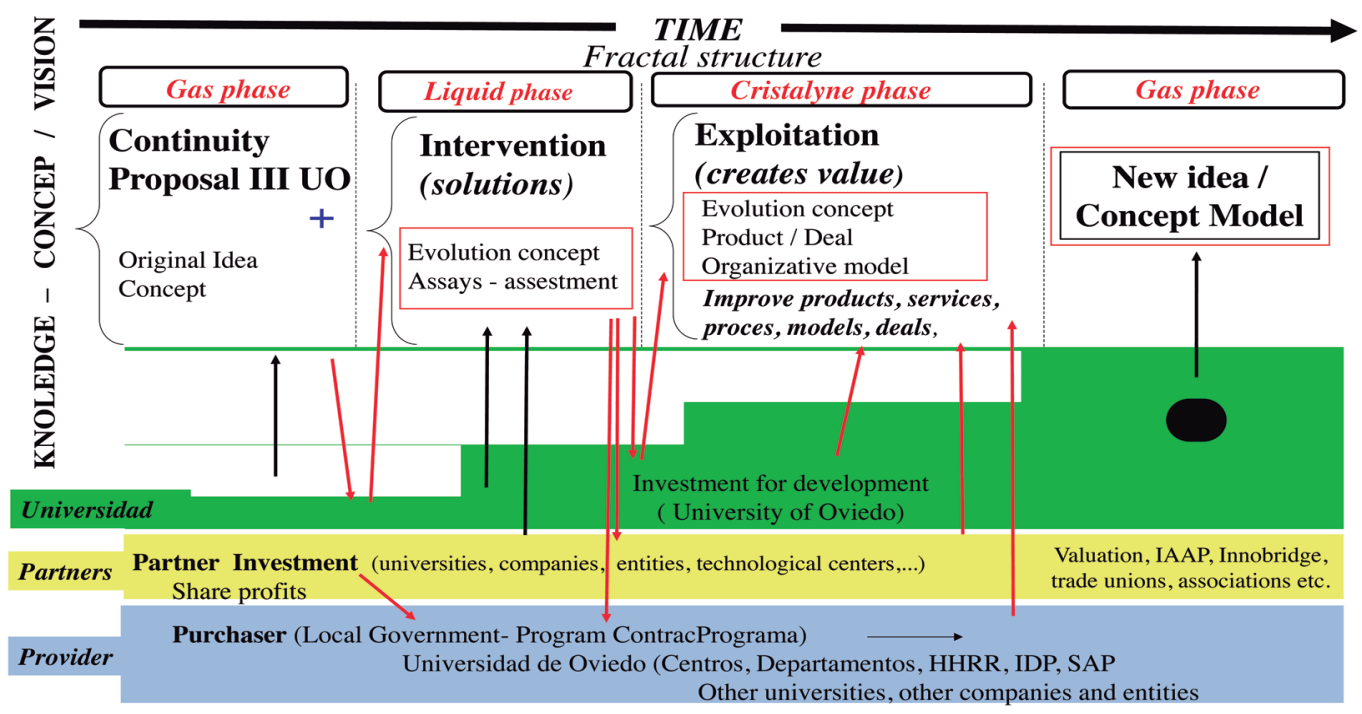

Figure 5. Fractal structure for innovation (Álvarez-Arregui and Arreguit. Taking into account the contributions of Elmar Mock, 2015; and Gilles E Elmar, 2016; ain the different temporal phases that occur in the development of vision) 


\section{Discussion and conclusions}

With the intention of evaluating the effectiveness of the inclusive training ecosystems with which we work, we make periodic investigations using quantitative and qualitative methodologies. The objective is to understand how the ecosystem affects the users' satisfaction in relation to the design of the presential and virtual work environment (Álvarez Arregui, Rodríguez Martín 2010), in learning styles (Álvarez Arregui, Rodríguez Martín, 2011), to the professionalism of teachers and students (Rodríguez Martín and Álvarez Arregui, 2011), to the use of resources and to the development of inter-institutional projects (Álvarez Arregui, Rodríguez Martín, Ribeiro Gonçalves, 2012), to the development of an entrepreneurial spirit (PérezBustamante, Álvarez Arregui and Rodríguez Martín, 2012) and to the institutional projection (Álvarez Arregui, Rodríguez Martín, 2012) among other issues.

In general, the results show that users consider as better professionals those who develop the content using the procedure followed within the training ecosystems. They also point out that with this approach a good balance is established between the theoretical and practical content and the development of Professional skills; they strive to make sure that the users understand the content transferred; they foster interest in the contents and promote creativity and entrepreneurship.

The institutional evaluations made by users about the professionals who deploy this model are better graded than those about the rest of the professors, and in the last two years' excellent appraisals have been obtained in the degrees in which it has been applied. When participating to one or two semesters in subjects developed under this methodology, they consider that lectures should be on a-need-basis and should not be used as a recurring resource, especially when teachers spend the available time on a mere repetition of information.

The group dynamics are highly valued in general, but are even more appreciated when collaborative work networks are created, integrating the contributions of different groups (students, teachers, external professionals, etc.). When this approach is adopted, users support continuous assessment if their teachers pay specific attention to the content, the generic competences developed, the degree of involvement demonstrated and the self-assessment of their own effort.

With respect to the use of the virtual environment, they emphasize its usefulness as a communication vehicle because it has increased the participation, the relationships and the collaboration. The blog and podcasts are described as very dynamic instruments that favor individual and collective management. Sometimes the contributions they have made of photographic, videographic and documentary materials made them feel as actors of the learning process and the generation of knowledge, which resulted in high doses of implication and motivation that is interpreted as an added value of the ecosystem. However, periodic monitoring is an element to keep in mind throughout the process.

Another strength that systematically stands out from working with these ecosystems is the sharing during face-toface sessions on the virtual campus, involving non-presential students and external professionals (blog, facebook, twitter and forums). This approach increases the degree of user satisfaction because it generates feelings of membership with colleagues and professionals who are in other universities (Erasmus, Socrates ...), making them partners of what happens in classes independently of being enrolled or not in these subjects.

Specific external visits, at least one and a maximum of three, are highly valued because they allow to establish professional relationships in other environments, bring them closer to other working methodologies and generate a sense of belonging to the group and to the learning model that is being developed. In this respect, it is also important to point out that some students return as listeners to previous classrooms after they finish the subjects and collaborate in all those activities that are required from EcosistemaP.

Although the results support the model, they also show some limitations that advice in particular to look at improvements in the initial diagnostic phase in order not to bureaucratize the processes, as well as to detect early limited communicative and technological skills of the model users. In this regard, it is necessary to continue to deepen the investigation of the support systems (peer tutoring) by giving them greater recognition in final assessments, improving access to quality knowledge (internal and external good practices) and promoting complementary courses or seminars, during and at the end of the ecosystem deployment.

The evaluation process has become more complex because the competences that students acquire differ according to the chosen modality and are not always homologable. This situation has forced us to write complementary qualitative reports including up to 18 indicators like the individual tasks, project planning, individual contributions to the group, use of the different virtual campus tools, quality of presentations, active dynamics, and support for colleagues with difficulties, among other issues. Stirivng to continue learning, every year we implement different initiatives to improve the model.

In our sketched scenario, we cannot forget that the University of the XXI century is deploying an additional mission in such a way that, together with teaching and research, enterprise management is being added, as well as social responsibility where governments must facilitate the conditions to promote the economic and social development of the areas in which it is located. Competing, collaborating and associating with companies, institutions and technological centers in the autonomous, national and international environments, in addition the Univerity must be efficient in the management of its resources and expand civic and human values in its areas of influence.

The task is not easy, but it becomes even more complicated if we consider that the energy required by the "propellers" to move the organizations (academic culture, business culture, social culture and political culture) comes from an entrepreneurial spirit, from ethics, equity, quality, transparency, excellence and sustainability. Any deviation will have to be corrected with periodic audits from inside and from outside, promoted by those agents, agencies, commissions and entities that are determined in each case to preserve the integrity of research, teaching and management from ethical codes assumed and backed politically, academically, socially and entrepreneurially in our cultural environment (Álvarez-Arregui, 2017).

The University of Oviedo is moving in this direction by consolidating a Campus of Excellence that is made available to the Autonomous Community of the Principality of Asturias to promote an Asturian Ecosystem of Knowledge, committed to society, inclusive and open to citizens at any point in time of their life and professional career. From this approach, we will continue to build research, training and innovation ecosystems that will become a viable and sustainable alternative over time to respond to the demands of continuous change demanded by today's society (Álvarez-Arregui, 2017). In this regard, we consider that (ob. cit.): 
- We have to turn crises into opportunities to grow personally, professionally, institutionally, communally and globally by taking advantage of the synergies that are occurring inside and outside university institutions.

- We need to promote inclusion, collaboration, predisposition and agreements between the political, academic, business and social environments to make them a reference and example for citizenship.

- We have to promote ecosystem projects that go beyond the usual political, academic, business and social proposals, involving citizens in what is happening and leaving the door open to debate and criticism.

- We have to look beyond our "comfort zone", open the doors to other professionals and project ourselves outside the walls of our organizations and institutions to increase our knowledge or improve it.

- We need to deploy new governance models where people with responsability of management, leadership and coordination are able to relate, contextualize and globalize in a sequential as well as simultaneous manner at different levels managing knowledge from a complexity and ethics perspective.

- We need to open up the possibility of managing a lifelong learning process to learn how to learn, learn how to change, learn how to accept change and learn how to live with change. In this way, the cultural action of the promoters of change is oriented towards the integration of the different subcultures so that there are no unrecoverable breakups between them, generating confrontations instead of collaboration.

- We have to open ourselves to the future with an ecoforming attitude that will help us to overcome the cellular structures of teachers, departments, faculties, schools and research institutes by strengthening the intermediate coordination structures from which to promote transformational, educational, inclusive and sustainable leadership.

- We have to establish solid bridges between different academic, business, social and political cultures to open paths towards intradisciplinarity, interdisciplinarity, transdisciplinarity, interdepartmentalism and interinstitutionality.

We are convinced that in an Information Society with aspirations to become a Knowledge Society, ecosystem models of inclusive research, training and innovation are a good alternative to conjugate the cultures of quality and equity, academic and business, teaching and research, politics and citizenship, among other issues.

In the scenario that has been drawn, we cannot forget that the great challenge of the Society and of the University in the XXI century is to train generations of citizens in the development of generic and specific competences, in entrepreneurial creativity, in critical capacity, in inclusion, in sustainability and in human solidarity. The future of Education, University and Society is our future, and to make it happen we must construct it with the collaboration of all the stakeholders.

\section{References}

Álvarez-Arregui, E. (2002). Acción directiva y cultura escolar. Influencia del liderazgo en el desarrollo institucional de los centros educativos. Oviedo: Servicio de Publicaciones de la Universidad de Oviedo.
Álvarez-Arregui, E. (2008). El Espacio Europeo de Educación Superior (EEES) desde una perspectiva de cambio. Lecturas sobre el continente y el contenido de la docencia. I Congreso Internacional Nuevas Bases para el Diseño de los Planes de Estudio en el EEES y su Incidencia en el Sistema Educativo: Ecoformación, Transdisciplinariedad e Interculturalidad. Madrid, España.

Álvarez-Arregui, E. (2010). La Universidad desde una perspectiva de cambio: En busca de la excelencia. I Congresso IberoBrasileiro. Elvas, Mérida, España.

Álvarez-Arregui, E. (2017). Presentación. En Álvarez-Arregui, E. (Coord.), Agudo-Martín, S., Rodríguez-Ruiz, B., ÁlvarezBlanco, L., García Cuesta, M. M. \& Llames Saldaña, J. S., Universidad, Investigación y Conocimiento: Avances y Retos. Oviedo. Universidad de Oviedo. 15-19.

Álvarez-Arregui, E., \& Rodríguez-Martín, A. (2011). Los desafíos de la Universidad en una Sociedad Global. Los ecosistemas de formación como propuesta de cambio. VIII Simposium Iberoamericano de Educación, Cibernética e Informática. Orlando, EEUU.

Álvarez-Arregui, E., \& Rodríguez-Martín, A. (2012). Ecosistemas de Formación Emprendedores. Una alternativa para la mejora de la docencia y el desarrollo profesional. Revista de Organización y Gestión de Centros Educativos (93) (1) Enero y Febrero (31-33)

Álvarez-Arregui, E., \& Rodríguez-Martín, A. (2013a). Gestión de la Formación en las Organizaciones desde una perspectiva de cambio. Principios básicos y estrategias de intervención. Oviedo: Ediuno.

Álvarez-Arregui, E., \& Rodríguez-Martín, A. (2013b). La cultura emprendedora como motor del cambio. Revista Aula de Innovación Educativa (220) 51-57.

Álvarez-Arregui, E., \& Rodríguez-Martín, A. (2014). Innovando a través de proyectos. Organización, Liderazgo y Compromiso. Editorial Ediuno. Universidad de Oviedo

Álvarez-Arregui, E., \& Rodríguez-Martín, A. (2015). Ecosistemas de formación para aprender a emprender a través de proyectos transdisciplinares. Revista de Organización y Gestión Educativa, № 2 marzo - abril 8-11.

Álvarez-Arregui, E., \& Rodríguez-Martín, A., \& Ribeiro Gonçalves, F. (2011). Ecosistemas de formación blendedlearning para emprender y colaborar en la universidad. Valoración de los estudiantes sobre los recursos. Revista Teoría de la Educación: Educación y Cultura en la Sociedad de la Información. 12(4), 7-24.

Álvarez-Arregui, E., Rodríguez-Martín, A., Madrigal Maldonado, R., Grossi-Sampedro, B. A. \& Arreguit, X. (2017). Ecosystem of Media Training and Competence: International Assessment of its Implementation in Higher Education. Revista Comunicar, no. 51, v. XXV, 115-114

Area, M. (2012). Sociedad líquida, web 2.0 y alfabetización digital. Aula de Innovación Educativa, 212, 55-59.

Buckland, R. (2009). Private and Public Sector Models for Strategies in Universities. British Journal of Management, 20(4), 524-536. (http://goo.gl/bPvxVt) (2016-11-25).

Cano, R. (2009). Tutoría universitaria y aprendizaje por competencias ¿cómo lograrlo? Revista Interuniversitaria de Formación del Profesorado, 12, 181-204. (http://goo.gl/ SwlBry) (11-11-2015)

Carrascosa, J. (2005). La evaluación de la docencia en los planes de mejora de la Universidad. Educación XXI, 8, 87-101. (http://goo.gl/J5E1gP) (2015-10-04)

Castells, M. (1999). La era de la información. Fin de milenio. Madrid: Alianza. 
Chang, V., \& Lorna, U. (2008). Governance for e-learning ecosystem. In E. Chang, \& F. Hussain (Ed.). Second IEEE International Conference on Digital Ecosystems and Technologies, 340-345. Phitsanulok (Thailand): Institute of Electrical and Electronics Engineers.

DeJaeghere, J. (2009). Critical Citizens Education for Multicultural Societies. Interamerican Journal of Education and Democracy, 2(2), 223-236. (https://goo.gl/XxOUBT) (2015-11-22).

Dimitrov, V. (2001). Learning Ecology for Human and Machine Intelligence: A Soft Computing Approach. Studies in Fuzziness and Soft Computing, 81, 386-393. (http://goo.gl/ TgXmvW) (2016-11-01).

Elmar, M. (2015). Personnal communication to Xavier Arreguit.

Entwistle, N., \& Tait, H. (1990). Approaches to learning, evaluations of teaching, and preferences for contrasting academic environments. Higher Education, 19, 169-194. (http://goo.gl/MKbfrs) (2016-08-09).

García-Galera, M.C. (2013). Twittéalo: la generación Y su participación en las redes sociales. Crítica, 985, 34-37. (http:// goo.gl/5DbdM9) (27-11-2015).

Gewerc, A., Montero, L., \& Lama, M. (2014). Colaboración y redes sociales en la enseñanza universitaria [Collaboration and Social Networking in Higher Education]. Comunicar, 42, 55-63. https://doi.org/10.3916/C42-2014-05

Gilles, G. \& Elmar, M. (2016). The Innovation Factory, Publishers Taylor \& Francis Inc, Productivity Press, 2016.

Gimeno Sacristán, J. (2001). Educar y convivir en la cultura global. Madrid: Morata.

Gimeno Sacristán, J. (2008). Educar por competencias. ¿Qué hay de nuevo? Madrid: Morata.

Gütl, C., \& Chang, V. (2009). Ecosystem-based Theorical Models for Learning in Environments of the 21st Century. International Journal of Emerging Technologies in Learning, 7, 1-11. (http://goo.gl/IhZOwg) (14-12-2015).

Ismail, J. (2001). The Design of an e-Learning System beyond the Hype. Internet and Higher Education, 4(3-4) 329-336. (http:// goo.gl/rqLPzA) (2015-12-17).

Kolloffel, B., Eysink, T., \& Jong, T. (2011). Comparing the Effects of Representational Tools in Collaborative and Individual
Inquiry Learning. Computer-Supported Collaborative Learning, 6, 223-235. (https://doi.org/10.1007/s11412-0119110-3)

León, B., \& Latas, C. (2005). Nuevas exigencias en el proceso de enseñanza-aprendizaje del profesor universitario en el contexto de la convergencia europea: la formación en técnicas de aprendizaje cooperativo. Revista Interuniversitaria de Formación del Profesorado, 8(6), 45-48. (http://goo.gl/h3hT61) (18-11-2015).

Monereo, C. (2009). Pisa como excusa. Repensar la evaluación para cambiar la enseñanza. Barcelona: Graó.

Ramsden, P., Martin, E, \& Bowden, J. (1989). School environment and sixth form pupils' approaches to learning. British Journal of Educational Psychology, 59(2), 129-142. https://doi. org/10.1111/j.2044-8279.1989.tb03086.x

Rodríguez-Martín, A. \& Álvarez-Arregui, E. (2014). Estudiantes con discapacidad en la Universidad. Un estudio sobre su inclusión Revista Complutense de Educación 25(2). 457-479. https://doi.org/10.5209/rev_RCED.2014.v25.n2.41683

Sánchez-Gómez, M.C., \& García-Valcárcel, A. (2002). Formación y profesionalización docente del profesorado universitario. Revista de Investigación Educativa, 20(1), 153-171. (http:// goo.gl/1sJr9n) (30-11-2015).

Senge, P.M. (1990). The Fifth Discipline. The Art and Practice of the Learning Organization. New York: Dobuleday.

Shimaa, O., Nasr, M., \& Helmy, Y. (2011). An Enhanced E-Learning Ecosystem Based on an Integration between Cloud Computing and Web 2.0. International Conference on Digital Ecosystems and Technologies. Corea: Dejeon.

Shrivastava, P. (1998). Knowledge Ecology: Knowledge Ecosystems for Business Education and Training. Lewisburg: Bucknell University Press.

Toffler, A. (1980). La tercera ola. Barcelona: Plaza \& Janes.

Uden, L., Wangsa, I.T., \& Damiani, E. (2007). The future of e-Learning: E-learning ecosystem. Digital EcoSystems and Technologies Conference, 7, 113 -117. https://doi.org/10.1109/ DEST.2007.371955.

Zabalza, M.A. (2002). La enseñanza universitaria. El escenario y sus protagonistas. Madrid: Narcea. 